\title{
Quality of surgical antibiotic prophylaxis using E-prescrption conditioning
}

\author{
JFC Rodrigues ${ }^{1 *}$, A Duarte $^{1,4}$, C Palos $^{2}$, A Casado ${ }^{2}$, C Santos $^{3}$, F Fernandez-Llimos ${ }^{4}$ \\ From International Conference on Prevention \& Infection Control (ICPIC 2011) \\ Geneva, Switzerland. 29 June - 2 July 2011
}

\section{Introduction / objectives}

Hospital da Luz is a paper-free hospital. Antibiotic prescription is made electronically and is automatically conditioned by both context and duration. We aimed to assess the pattern of use of antibiotics in surgical prophylaxis in a general hospital.

\section{Methods}

Prophylactic antibiotic prescriptions for patients undergoing surgery in January 2011 were extracted from the medical records. Variables collected included: surgical procedure, prophylactic antibiotic prescribed (ATC code), surgery classification (clean, clean contaminated, contaminated and dirty), and prophylaxis duration. A descriptive statistical analysis and cross-tabulations (chisquare) were performed.

\section{Results}

611 prophylactic antibiotics were initiated for patients with an average age of 49.6 years $(S D=16.6),(60.6 \%$ females). Surgeries were classified as: clean (39.1\%), clean contaminated $(29.4 \%)$, contaminated $(2.1 \%)$ and dirty $(1.2 \%)$. Most prescribed antibiotics were: first-generation cephalosporins (83.6\%), second-generation cephalosporins $(8.0 \%)$, imidazole derivatives $(4.6 \%)$ and quinolones (1.8\%). Antibiotic administration was exclusively intraoperative in $50.8 \%$ of the cases. $34.5 \%$ of the prescriptions were extended for 24 hours, $12.4 \%$ for 48 hours and $2.3 \%$ for more than 48 hours. Statistical association between surgery classification and treatment duration was found (chi-square $\mathrm{p}=0.010$ ). Quinolones were prescribed only in urological surgery and imidazoles were prescribed only in colorectal surgery.

'Pharmacyst, Lisbon, Portugal

Full list of author information is available at the end of the article

\section{Conclusion}

Antibiotic prophylaxis using e-prescription conditioning resulted on adequate compliance with guidelines, although opportunities for improvement were found.

\section{Disclosure of interest}

None declared.

\section{Author details}

${ }^{1}$ Pharmacyst, Lisbon, Portugal. ${ }^{2}$ ICU Physician, Hospital Da Luz, Lisbon, Portugal. 'Head of Pharmaceutical Department, Hospital Da Luz, Lisbon, Portugal. ${ }^{4}$ iMed.UL, Faculty of Pharmacy, University of Lisbon, Lisbon, Portugal.

Published: 29 June 2011

\section{doi:10.1186/1753-6561-5-S6-O44}

Cite this article as: Rodrigues et al:: Quality of surgical antibiotic prophylaxis using E-prescrption conditioning. BMC Proceedings 20115 (Suppl 6):O44.
Submit your next manuscript to BioMed Central and take full advantage of:

- Convenient online submission

- Thorough peer review

- No space constraints or color figure charges

- Immediate publication on acceptance

- Inclusion in PubMed, CAS, Scopus and Google Scholar

- Research which is freely available for redistribution

Submit your manuscript at www.biomedcentral.com/submit
() Biomed Central

\section{() Biomed Central}

